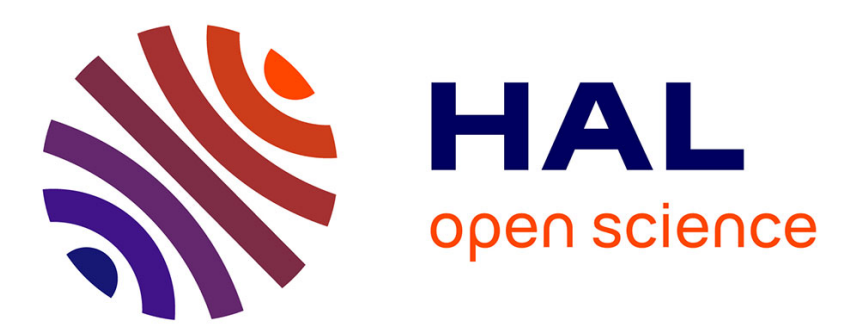

\title{
Wet Deposition Fluxes of Mineral Dust and Their Relation With Cold Pools in the Central Sahel
}

T. Audoux, B. Laurent, B. Marticorena, G. Bergametti, J. L Rajot, A. Féron, C. Gaimoz

\section{- To cite this version:}

T. Audoux, B. Laurent, B. Marticorena, G. Bergametti, J. L Rajot, et al.. Wet Deposition Fluxes of Mineral Dust and Their Relation With Cold Pools in the Central Sahel. Geophysical Research Letters, 2022, 49 (4), pp.e2021GL095005. 10.1029/2021GL095005 . hal-03565629

\section{HAL Id: hal-03565629 \\ https://hal.science/hal-03565629}

Submitted on 11 Feb 2022

HAL is a multi-disciplinary open access archive for the deposit and dissemination of scientific research documents, whether they are published or not. The documents may come from teaching and research institutions in France or abroad, or from public or private research centers.
L'archive ouverte pluridisciplinaire HAL, est destinée au dépôt et à la diffusion de documents scientifiques de niveau recherche, publiés ou non, émanant des établissements d'enseignement et de recherche français ou étrangers, des laboratoires publics ou privés. 
Wet deposition fluxes of mineral dust and their relation with cold pools in the Central Sahel

\author{
T. Audoux ${ }^{1}$, B. Laurent ${ }^{1}$, B. Marticorena ${ }^{2}$, G. Bergametti ${ }^{1}$, J.L. Rajot ${ }^{1,3}$, A. Féron ${ }^{1}$, and C. Gaimoz ${ }^{2}$
}

${ }^{1}$ Université de Paris and Univ Paris Est Creteil, CNRS, LISA, F-75013 Paris, France, ${ }^{2}$ Univ Paris Est Creteil and Université de Paris, CNRS, LISA, F-94010 Créteil, France, ${ }^{3}$ iEES Paris, UMR IRD 242, Univ Paris Est Creteil-Sorbonne Université-CNRS-INRA-Université de Paris, Bondy, France

Corresponding author: T. Audoux (taudoux@lisa.ipsl.fr)

Key Points:

- More than 240 sahelian wet deposition events were classified according to the intensity of the associated cold pools

- Rain events associated with cold pools contribute up to $80 \%$ of the annual wet deposition

- Washout ratios of the most convective rains under high level of dust concentrations in the Sahel is around 495 [319-766]

\title{
Abstract
}

Based on a large number of in-situ measurements performed over a 9-years period in two Sahelian stations, we investigate the drivers of the dust wet deposition in relation to the meteorological situations and the $\mathrm{PM}_{10}$ (Particulate Matter with diameter lower than $10 \mu \mathrm{m}$ ) surface concentrations. Precipitation associated with cold pools (CP) contribute to more than $90 \%$ of the precipitation amount associated with the collected wet deposition samples. The wet deposition events associated with these $\mathrm{CP}$ control by far the wet deposition, i.e., $66 \%$ and $81 \%$, depending on the station. The dust washout ratios (WR) corresponding to the most convective events under high level of dust concentrations were found to be in the range of 319-766 while WR of other kind of events are depending on the dilution effect. This range of value are in the lower range of WR previously estimated and used in dust modelling studies (200 - 2000).

Plain Language Summary

Mineral dust emitted in the atmosphere by wind erosion in arid and semi-arid areas have environmental impacts on the climate, human health and on bio-geochemical cycles. The atmospheric concentrations are controlled by both emission and deposition processes. In this study, we focus on the study of wet deposition of mineral dust in the Sahel semi-arid region. Long-term (9-years) measurements of dust concentrations, wet dust deposition and meteorological parameters 
Atmospheric chemistry in Africa) are presented. Based on this dataset, we investigated the cold pool meteorological situation associated to wet deposition of mineral dust.

\section{Introduction}

Mineral dust is emitted in the atmosphere by the wind erosion of arid and semi-arid surfaces (e.g., Bagnold, 1941; Pye, 1987). This emission only occurs when the surface wind speed exceeds the wind speed threshold for wind erosion that depends mainly on soil and surface characteristics (e.g., Bagnold, 1941; Marticorena \& Bergametti, 1995; Shao \& Lu, 2000). Despite dust emissions are pulsed and sporadic as a consequence of this threshold, global dust emissions represent more than $40 \%$ of the annual mass of particulate injected into the atmosphere, i.e., between 1000 and 4000 $\mathrm{Mt} \mathrm{yr}^{-1}$ (e.g., Boucher et al., 2013).

Wet deposition is a major removal process for atmospheric dust particles and thus a key process regarding the aerosol cycle (e.g., Textor et al., 2006). The Sahel is a semi-arid region where dust scavenging by rain is an important process for dust deposition. During the wet season, that extends from May to October, the Sahel is under the influence of the African monsoon which flows moist air from the Gulf of Guinea and controls the majority of the water fallout in the Sahelian band. At that time, air mass conflicts between hot and dry Saharan flow and the moist monsoon air occur on the northern part of the Inter-Tropical Front while the surface heating favors convection. This leads to Mesoscale Convective Systems (MCSs) that are organized convective cells, frequently followed by a stratiform region that can concern a contiguous rain area approaching up-to $100 \mathrm{~km}$ in horizontal scale in at least one direction (A.M.S, 2015; Houze, 1997). During the rainy season, $12 \%$ of the MCSs is responsible of $90 \%$ of the total rain amount (Lebel et al., 2003; Nicholson, 2013 ) and the most intense ones (3-4\% of therain events) contribute up to $80 \%$ of the rainfall in the Sahel (Nesbitt \& Zipser, 2003; Nicholson, 2013). Cold pools (CP) are the outcome of mesoscale density currents that originate from the exchange of latent heat of evaporation underneath precipitating clouds into deep convective downdrafts (e.g., Harrison et al., 2021). Thus, they participate in the development of new convective cells, being therefore a key mechanisms of MCSs (e.g., Provod et al., 2016; Wilson and Schreiber, 1986). MCSs and the associated cold pools are not only the main cause of the total rain production and its variability in the Sahel (Laurent et al., 1998; Mathon et al., 2002; Vischel et al., 2019) but also a major process responsible for huge dust uplift during the rainy season (Kaly et al., 2015; Marsham et al., 2008; Marticorena et al., 2010; Williams et al., 2009).

Several studies investigated the atmospheric load as well as the deposition in the Sahel (e.g., Drees et al., 1993; Orange, 1990; Ramsperger et al., 1998; Rott, 2001). More recently, the spatial and temporal variability of mineral dust deposition in the Central Sahel has been analysed by Marticorena et al. (2017) using 7 years of continuous measurements. These authors have documented the occurrence of deposition events as well as associated parameters such as aerosol concentrations and meteorological conditions. They showed the existence of a decreasing gradient of the deposition flux from east to west congruent with, but not proportional to, the $\mathrm{PM}_{10}$ concentration gradient. The dust deposition also exhibits a strong seasonal cycle linked to the wet season and wet deposition has been shown to be one of the main drivers of the variability of the total dust deposition from the seasonal to inter-annual scales in the Central Sahel. Indeed, these 
authors exhibited that the annual contribution of the wet deposition to the total deposition represented on average 67 and 52\% in Cinzana (Mali) and Banizoumbou (Niger), respectively. The wet deposition is dominant during the wet season in this region and represent 66 to $77 \%$ of total deposition from May to September in Banizoumbou and from 65 to $100 \%$ of total deposition from May to October in Cinzana (Marticorena et al., 2017).

In this paper, we focus on the conditions that control the intensity of the dust wet deposition occurring in the Central Sahel. Cold pools have been shown to be a frequent meteorological phenomena leading to strong winds, precipitation and dust lifting in the Sahel (e.g., Knippertz et al., 2009; Williams et al., 2009) and should be important regarding the wet deposition too. Longterm monitoring of deposition events, aerosol and meteorological data measured conjointly in two locations in the Sahelian band from 2007 to 2015 at high resolution allow to investigate how different types of precipitation events affect the dust wet deposition. In addition, the contribution of wet deposition events associated to cold pools to the total wet deposition in the Sahel as well as the efficiency of wet deposition through washout ratios are discussed.

\section{Materials and Methods}

The following analysis is based on the large dataset acquired in two stations of the INDAAF network (International Network to study Deposition and Atmospheric chemistry in Africa). These stations, located in the Central Sahel, at Banizoumbou (Niger) and Cinzana (Mali), serve as a Sahelian long-term observatory to document dust concentration and deposition since their installation in 2006 (Kaly et al., 2015; Marticorena et al., 2010, 2017).

104

Briefly, the Banizoumbou station is situated in a fallow at $2.5 \mathrm{~km}$ from the village of Banizoumbou at $60 \mathrm{~km}$ east of Niamey in Niger $\left(13.54^{\circ} \mathrm{N}, 2.66^{\circ} \mathrm{E}\right)$ while the Cinzana station is located in an agronomical research station of the Institut d'Economie Rurale localized at $40 \mathrm{~km}$ east south-east of Segou in Mali $\left(13.28^{\circ} \mathrm{N}, 5.93^{\circ} \mathrm{W}\right)$. Between 2007-2015, precipitation in Banizoumbou is ranging from 311 to $767 \mathrm{~mm} \mathrm{yr}^{-1}$ while in Cinzana, precipitation is ranging between 457 and 925 $\mathrm{mm} \mathrm{yr}^{-1}$. A detailed description of the sites can be found in Marticorena et al. (2010).

Rainfall was monitored using an ARG100 tipping bucket rain gauge $(0.2 \mathrm{~mm}$ precision). In parallel, other parameters characterizing the air masses at the surface have been measured such as air temperature, relative humidity using 50Y, HMP50 or HMP60 Vaisala sensor and wind direction and speed using a Windsonic 2-D Gill Instruments ${ }^{\odot}$. All measurements have been registered using instrumentation from Campbell Scientific ${ }^{\odot}$.

Dust concentrations were measured using a Tapered Element Oscillating Microbalance (TEOM 1400A, Thermo Scientific). The instrument is equipped with a $\mathrm{PM}_{10}$ inlet, i.e., with a $50 \%$ efficiency cut-off for aerodynamic diameter smaller than $10 \mu \mathrm{m}$. The meteorological measurements and the $\mathrm{PM}_{10}$ concentrations are recorded as 5-minute averages since 2006.

We used two criteria to define a rain event: (i) a rain event corresponds to a cumulated rainfall strictly higher than $0.2 \mathrm{~mm}$, i.e., the detection limit of the rain gauge; (ii) we consider that two rain 
123

124

125

126

127

128

129

130

131

132

133

134

135

136

events are distinct from each other if the end of one event and the beginning of the following is separated by at least 3 hours without rain. Based in these criteria, 520 rain events ranging from 0.4 to $115 \mathrm{~mm}$ (mean=11.8 $\mathrm{mm}$, median=6.6 mm) and 363 rain events from 0.4 to $80.2 \mathrm{~mm}$ (mean=11.4 mm, median=5.6 mm) have been collected over the period 2007-2015 in Cinzana and in Banizoumbou, respectively.

Wet deposition is collected using a MTX ARS 1010 automatic deposition sampler (MTX Italia SPA, Modane, Italy) installed at $5.2 \mathrm{~m}$ high in Banizoumbou and Cinzana. The sampler is equipped with a humidity sensor that detects the beginning of each rain event and allow the collection of the wet deposition only. Wet deposition was sampled continuously from 2007 to 2015 . This allowed to collect 288 wet deposition samples in Banizoumbou and 358 wet deposition samples in Cinzana. Samples are recovered most of the time after each precipitation by the local operators or at least weekly. In this latter case, a wet deposition sample can contain several wet deposition events.

\subsection{Classification of rain events}

Most of the rain events occuring in the Sahel are associated with MCSs within which the convective precipitation progressively transforms into stratiform precipitation. Because we have observations in a given place, the rain events we sampled do not correspond to the same stages of evolution of MCS. Thus, our data set mixes both convective, stratiform and mixed rain events. The different phases of MCS can be characterized at the surface by the temperature of the CP that informs on the intensity of the downdrafts and thus on the convection and by other surface meteorological parameters such as wind speed and direction (e.g., Flamant et al., 2009; Knippertz et al., 2009).

Indeed, Provod et al. (2016) have described the surface properties of Sahelian CP in Niamey (Niger) during the 2006 wet season showing that CP events are characterised by simultaneous temperature decrease, surface pressure increases and a sudden increase in wind speed.

Following this work, we computed for each rain event the changes in wind speed and temperature as the difference between the minimum wind speed (maximum temperature) observed during the 60 minutes preceding the onset of the rain and the maximum wind speed (minimum temperature) observed during the 120 minutes following the onset of the rain. We also computed the maximum change in wind direction occurring within 30 minutes. The method to identify CP is mainly based on the study of Provod et al. (2016). Rain events are classified as CP when associated simultaneously with a change in wind direction of at least $30^{\circ}\left(\Delta \mathrm{Dir} \geq 30^{\circ}\right)$, a decrease in temperature of at least $2^{\circ} \mathrm{C}\left(\Delta \mathrm{T} \geq 2.0^{\circ} \mathrm{C}\right)$ and an increase in wind speed $\left(\Delta \mathrm{V}<0 \mathrm{~m} \mathrm{~s}^{-1}\right)$, the other rain events being classified as NCP (Non Cold Pool). However, in addition to automated processing, each event was verified individually to confirm whether it belonged to $\mathrm{CP}$ or NCP classification. 274 and 398 rain events were associated with $\mathrm{CP}$ while 90 and 122 rain events corresponded to NCP situations in Banizoumbou and Cinzana, respectively.

\subsection{Washout ratio}

The washout ratio, WR, is generally used to quantify the efficiency of wet deposition mechanisms for a rain event (i.e., washout and rainout). WR is defined as the ratio of the concentration of a species in the rain water $\left(\mathrm{C}_{\text {rain }}\right)$ divided to the mean surface concentration in the air $\left(\mathrm{C}_{\text {air }}\right)$ of the 
rain event (e.g., Chamberlain, 1960), $\rho_{\text {air }}$ and $\rho_{\text {rain }}$ being respectively the density of air (here expressed in $\left.\mu \mathrm{g} \mathrm{m}^{-3}\right)$ and of rain $\left(\mathrm{mg} \mathrm{L}^{-1}\right)$ :

$$
W R=\frac{c_{\text {rain }}}{c_{\text {air }}} \times \frac{\rho_{\text {air }}}{\rho_{\text {rain }}}
$$

WR has been documented for different environment (e.g., Cerqueira et al., 2010; Ducret \& Cachier, 1992; Encinas et al., 2004; Guerzoni et al., 1995; Marticorena et al., 2017). However, its application has been largely debated because of the many assumptions that are generally required for its computation (e.g., Gatz, 1974; Slinn, 1974). Indeed, if WR is based on parameters that can be easily measured (e.g., surface mean aerosol concentrations), the potential impact of large spectras of droplet and dust is neglected and the atmospheric concentration of deposited atmospheric compounds has to be assumed uniformly mixed below the cloud base.

WR of mineral dust have mostly been determined using concentration measurements in areas very far from dust sources (e.g., Arimoto et al., 1987; Duce et al., 1991; Prospero et al., 1987) and only a few studies have calculated WRs for rain events in the vicinity of emission sources. Despite its limitation, WR remains used for modelling dust wet deposition in global climate models generally using constant value of WR (Ginoux et al., 2001; Jung \& Shao, 2006; Tegen \& Fung, 1994). It remains interesting to better constrain this parameter. Moreoever, WR is also used to provide an estimation of the wet deposition fluxes when only atmospheric particulate concentrations are measured (Cheng et al., 2021; Gatz, 1974).

Dust wet deposition results both from the wash-out and of the rain-out of particles by cloud and/or rain dropplets.

Washout of aerosol particles by rain depends on the probability of collision between a raindrop and a particle (Slinn, 1974). We assume in first approximation that the number of droplets is proportional to the amount of measured precipitation and that the $\mathrm{PM}_{10}$ concentrations is a proxy for the number of aerosol particles in the atmosphere.These assumptions consist of considering that the size-distributions of raindrops and of aerosol particles is monomodal (or very tight) and do not change over time. Since at each 5-minute time step, the dust concentration and the rainfall change, we estimate the mean particulate concentrations during a rain event by weighting the $\mathrm{PM}_{10}$ concentrations measured at a time step i by the amount of rain that fell during the same time step $\mathrm{i}$ as follows:

$$
C_{\text {air }}=\sum_{i} C_{P M 10, i}\left(\mu \mathrm{g} \mathrm{m}^{-3}\right) \times \frac{P_{i}(\mathrm{~mm})}{P_{\text {tot }}(\mathrm{mm})}
$$

$\mathrm{C}_{\mathrm{PM} 10, \mathrm{i}}$ being the $\mathrm{PM}_{10}$ surface concentration and $\mathrm{P}_{\mathrm{i}}$, the precipitation amount at the time step $\mathrm{i} ; \mathrm{P}_{\text {tot }}$ the precipitation amount of the rain event.

This allows to better represent the variation of $\mathrm{PM}_{10}$ concentrations regarding the rainfall time steps during the event. One should keep in mind that the use of $\mathrm{PM}_{10}$ concentrations to represent desert dust atmospheric content does not allow to account for the coarser dust that could constitute a significant fraction of atmospheric concentrations and deposition. Here, $\mathrm{PM}_{10}$ concentration are considered as a proxy of the whole dust concentration (see supplement information for further details).

To compute WR, we have to assume that the dust concentrations we measured at the surface are representative of the ones below the precipating cloud for $\mathrm{CP}$ events and that wash out is largely predominant compared to rain-out. These assumptions are probably fulfilled only in the case of 
well established convective events. During such events, atmospheric dust content is dominated by local dust emission. Desboeufs et al. (2010) have shown, using a sequential rain collector, that the wash-out process is by far the main contributor to the dust content of the first $\mathrm{mm}$ of rainfall and that dust contained in these first $\mathrm{mm}$ are predominant in the total wet deposited mass in the Sahel. Moreover, during intense convective events, the emitted dust particles are deeply mixed in the atmospheric column by the intense turbulence making the hypothesis of surface dust concentrations representative of the concentration in the atmospheric column reasonable.

Thus, we selected only convective precipitation (CP) events to examine the relationship between $\mathrm{PM}_{10}$ concentrations and rainwater concentrations. Leary \& Houze (1979) indicated that convective rains are most of the time associated with mean rainfall rate of $10 \mathrm{~mm} \mathrm{~h}^{-1}$ or more. The same threshold have been used by Nzeukou et al. (2004) to study convective rains in Senegal. Schumacher \& Houze (2006), using TRMM (Tropical Rainfall Measuring Mission Precipitation Radar) observations, have found that convective rains, in west Africa, have a mean intensity of 14 $\mathrm{mm} \mathrm{h}^{-1}$.

Thus, we separate $\mathrm{CP}$ events depending on their mean rainfall rate $(\mathrm{R})$, higher and lower than 10 $\mathrm{mm} \mathrm{h}^{-1}$, to compute WR. CP events with $\mathrm{R} \geq 10 \mathrm{~mm} \mathrm{~h}^{-1}$ being considered as the most convective events.

\section{Results}

\subsection{General characteristics of the rain events}

Figure 1 reports the temporal evolution of the mean of the surface meteorological parameters and $\mathrm{PM}_{10}$ for $\mathrm{CP}$ and $\mathrm{NCP}$ events, centered around the beginning of the rain events. In Banizoumbou, $\mathrm{CP}$ events are characterized by simultaneous temperature decrease $\left(7.7 \pm 3.5^{\circ} \mathrm{C}\right)$ and increase in wind speed $\left(7.3 \pm 3.6 \mathrm{~m} \mathrm{~s}^{-1}\right)$ while NCP events are followed by a lower temperature decrease $\left(2.1 \pm 4.0^{\circ} \mathrm{C}\right)$ and a lower increase in wind speed $\left(2.3 \pm 1.8 \mathrm{~m} \mathrm{~s}^{-1}\right)$. A similar behaviour is observed in Cinzana, where $\mathrm{CP}$ events exhibited simultaneous temperature decrease of $7.9 \pm 3.6^{\circ} \mathrm{C}$ and wind speed increase of $4.3 \pm 2.0 \mathrm{~m} \mathrm{~s}^{-1}$ and of $2.2 \pm 1.8^{\circ} \mathrm{C}$ and $1.6 \pm 1.2 \mathrm{~m} \mathrm{~s}^{-1}$ for NCP events. With regard to the rainfall rate, $\mathrm{CP}$ events are characterized by a mean (median) rainfall rate of $11.4(9.2) \mathrm{mm}$ $\mathrm{h}^{-1}$ in Banizoumbou and $11.1(8.7) \mathrm{mm} \mathrm{h}^{-1}$ in Cinzana while NCP events have an average rain intensity of 6.8 (4.0) and $5.4(3.7) \mathrm{mm} \mathrm{h}^{-1}$, respectively. Rainfall structures of CP and NCP have similar pattern with higher mean rainfall rates computed over $5 \mathrm{~min}$ (up to $20 \mathrm{~mm} \mathrm{~h}^{-1}$ for CP and $5 \mathrm{~mm} \mathrm{~h}^{-1}$ for NCP events) at the beginning of the rain events that decreases after 5 to 15 minutes. 
(a) Banizoumbou
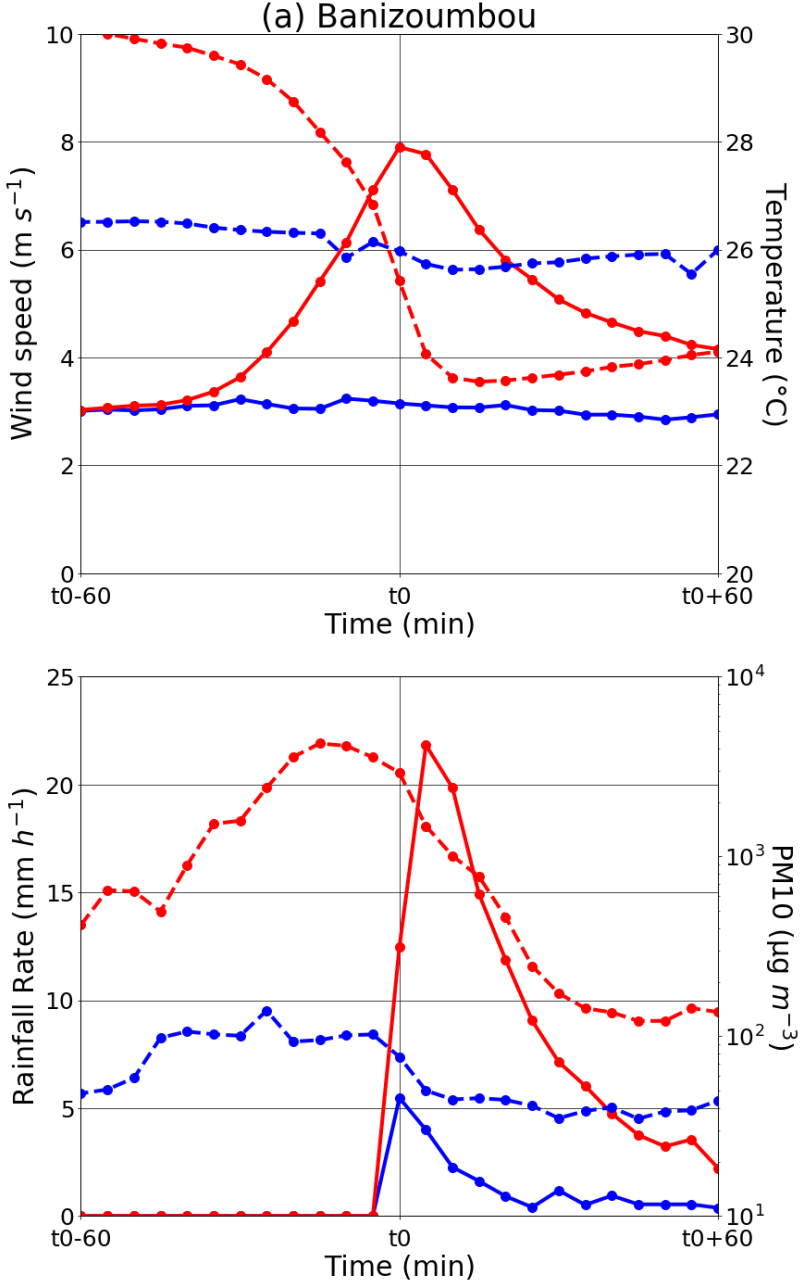

(b) Cinzana
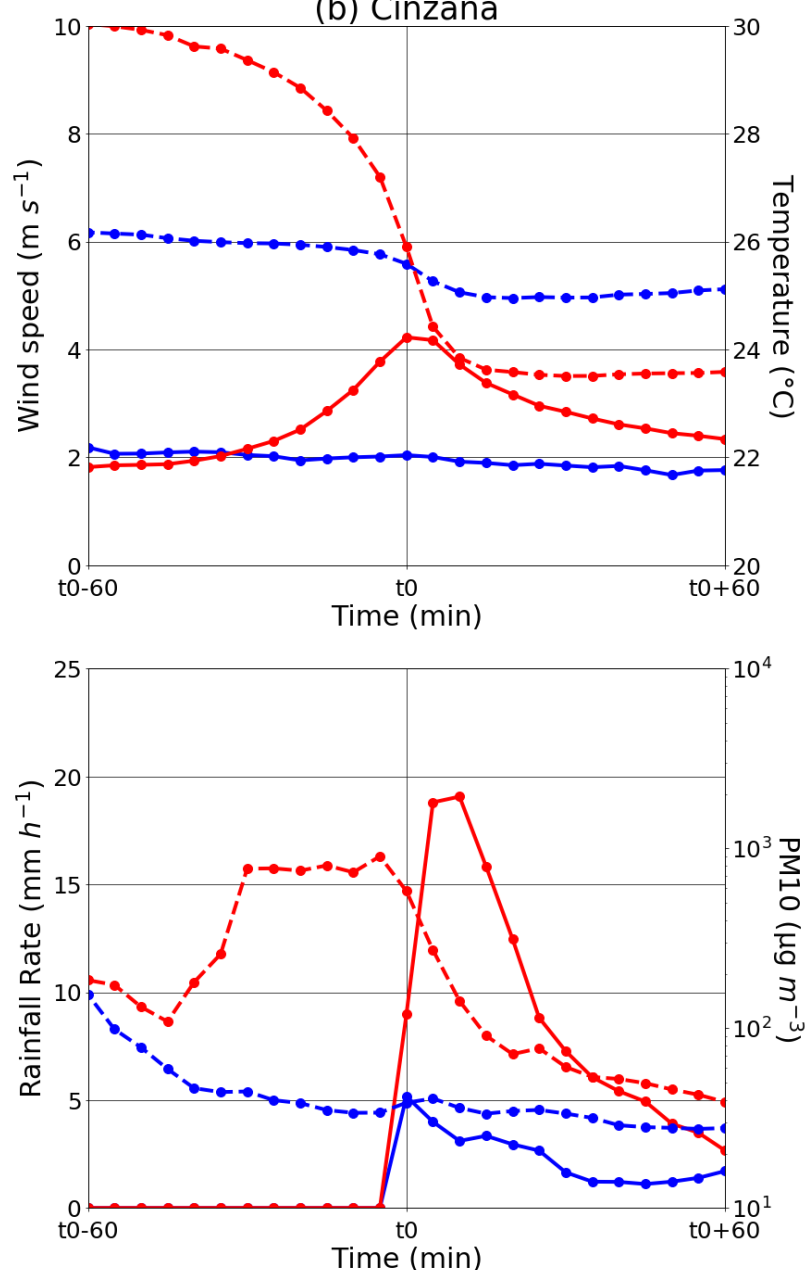

Figure 1. Mean surface temperature, wind speed, rainfall rate and $\mathrm{PM}_{10}$ concentration of the identified meteorological situations in two sites, on the left Banizoumbou (216 CP and $60 \mathrm{NCP}$ ) and on the right Cinzana (377 CP and $110 \mathrm{NCP}$ ). CP and NCP events are represented in red and blue, respectively. Solid lines correspond to left-hand axis and dashed lines correspond to righthand axes. t0 corresponds to the start of the rain.

$\mathrm{CP}$ events are characterised by an increase of $\mathrm{PM}_{10}$ concentrations as a consequence of the increase of wind speed. Indeed, wind speed and $\mathrm{PM}_{10}$ concentrations increase and reach a maximum during the 30 minutes preceding the onset of the rain but for a short duration, with an average of 10 to 15 minutes. When the rain starts, $\mathrm{PM}_{10}$ concentrations decrease until they reach values that are generally lower than those recorded before the rain event starts. Even if the general pattern is similar on both sites, it can be noted that wind speed and $\mathrm{PM}_{10}$ concentrations are significantly higher in Banizoumbou than in Cinzana.

Regarding NCP events, not any significant increase in $\mathrm{PM}_{10}$ concentrations before the beginning of the rain nor any variation during the rain event is observed, the wind speed never exceeding the minimum threshold wind speed for erosion (of the order of 7.0 and $5.5 \mathrm{~m} \mathrm{~s}^{-1}$ for Banizoumbou and Cinzana, respectively; Abdourhamane Toure et al., 2011; Bergametti et al., 2017). 
Table 1. Contribution (\%) by types of rain event to the rainfall and annual wet deposition fluxes. * Years with missing meteorological data in Banizoumbou. Average values in the text do not take into account these years for their computation.

\begin{tabular}{|c|c|c|c|c|c|c|c|c|c|}
\hline & 2007 & $2008 *$ & $2009 *$ & 2010 & 2011 & 2012 & 2013 & $2014 *$ & 2015 \\
\hline Banizoumbou & \multicolumn{8}{|c|}{ Wet deposition fluxes } \\
\hline CP & $61,7 \%$ & $88,1 \%$ & $93,4 \%$ & $45,5 \%$ & $77,5 \%$ & $71,6 \%$ & $66,0 \%$ & $76,6 \%$ & $72,9 \%$ \\
\hline NCP & $1,4 \%$ & $0,0 \%$ & $1,4 \%$ & $0,0 \%$ & $0,4 \%$ & $2,5 \%$ & $0,7 \%$ & $16,2 \%$ & $2,4 \%$ \\
\hline NA & $36,9 \%$ & $11,9 \%$ & $5,2 \%$ & $54,5 \%$ & $22,1 \%$ & $25,9 \%$ & $33,2 \%$ & $7,2 \%$ & $24,7 \%$ \\
\hline & \multicolumn{8}{|c|}{ Rainfall } \\
\hline CP & $96,4 \%$ & $98,6 \%$ & $97,8 \%$ & $91,1 \%$ & $97,5 \%$ & $85,9 \%$ & $94,0 \%$ & $95,1 \%$ & $94,0 \%$ \\
\hline NCP & $3,6 \%$ & $1,4 \%$ & $2,2 \%$ & $8,9 \%$ & $2,5 \%$ & $14,1 \%$ & $6,0 \%$ & $4,9 \%$ & $6,0 \%$ \\
\hline Cinzana & \multicolumn{8}{|c|}{ Wet deposition fluxes } \\
\hline CP & $95,5 \%$ & $88,2 \%$ & $83,4 \%$ & $86,1 \%$ & $88,5 \%$ & $85,6 \%$ & $47,8 \%$ & $74,5 \%$ & $78,4 \%$ \\
\hline NCP & $4,3 \%$ & $3,7 \%$ & $11,0 \%$ & $4,6 \%$ & $3,4 \%$ & $2,1 \%$ & $14,7 \%$ & $17,4 \%$ & $4,7 \%$ \\
\hline NA & $0,2 \%$ & $8,1 \%$ & $5,6 \%$ & $9,2 \%$ & $8,1 \%$ & $12,3 \%$ & $37,6 \%$ & $8,1 \%$ & $16,8 \%$ \\
\hline \multicolumn{8}{|c|}{ Rainfall } \\
\hline CP & $91,4 \%$ & $93,5 \%$ & $76,9 \%$ & $92,3 \%$ & $86,9 \%$ & $95,0 \%$ & $93,2 \%$ & $92,4 \%$ & $95,5 \%$ \\
\hline NCP & $8,6 \%$ & $6,5 \%$ & $23,1 \%$ & $7,7 \%$ & $13,1 \%$ & $5,0 \%$ & $6,8 \%$ & $7,6 \%$ & $4,5 \%$ \\
\hline
\end{tabular}

Over the 2007 - 2015 period, the annual number of CP events ranges from 24 to 36 (mean=30) in Banizoumbou and from 31 to $56($ mean=44) in Cinzana. The CP events in the Sahel represent $78 \%$ of the rain events measured in Banizoumbou and in Cinzana. Despite the annual variability, the contribution of CPs and NCPs events to rainfall is roughly similar from one year to the next : CP events contribute for $93 \pm 4 \%$ in Banizoumbou and for $91 \pm 6 \%$ in Cinzana (Table 1).

Between 2007 and 2015, the wet deposition fluxes range from 38.0 to $117.6 \mathrm{~g} \mathrm{~m}^{-2} \mathrm{yr}^{-1}$ and from 43.2 to $116.2 \mathrm{~g} \mathrm{~m}^{-2} \mathrm{yr}^{-1}$ in Banizoumbou and Cinzana, respectively, i.e., exhibiting an interannual variability of a factor of three at both sites. The wet deposition contributes for $50 \pm 12 \%$ and $71 \pm 20 \%$ of the total deposition in Banizoumbou and Cinzana, respectively.

In this paper, we focus on rainy events for which concomitant information on the meteorological parameters, wet deposition fluxes and $\mathrm{PM}_{10}$ concentrations measurements is available. Among these, we considered only those corresponding to a single rain event or due to a single rain type (i.e., CP or NCP). These events contribute for $55 \pm 15 \%$ of the annual wet deposition fluxes in Banizoumbou and $77 \pm 12 \%$ in Cinzana, respectively. The contribution of CPs and NCPs events is roughly the same each year (Table 1). CP events contribute to $66 \pm 11 \%$ of the annual wet deposition fluxes in Banizoumbou and to $81 \pm 14 \%$ in Cinzana while NCP events contribute to $1 \pm 1 \%$ and $7 \pm 6 \%$ of the annual wet deposition fluxes in Banizoumbou and Cinzana, respectively. The remaining part, corresponding to samples composed of different rain types, are not attributable to a specific type of rain events and are classified as NA (Table 1). It must be noted that the biggest wet deposition sample contribute in average to $30 \pm 10 \%$ of the annual wet deposition fluxes in Banizoumbou and to $26 \pm 13 \%$ in Cinzana.

\subsection{Washout Ratios}

Figures $2(a-b)$ show that there is a significant relationship between $C_{\text {rain }}\left(C_{\text {rain }}=F_{w}{ }^{\text {event }} / P\right)$ and $\mathrm{C}_{\text {air }}$ for $\mathrm{CP}$ events regardless of their rainfall rate, $\mathrm{F}_{\mathrm{w}}{ }^{\text {event }}$ being the wet deposition flux of the rain 
event. However, values are less scattered for $\mathrm{CP}$ events with $\mathrm{R}>10 \mathrm{~mm} \mathrm{~h}^{-1}$, thus the relationship between the two variables is stronger $\left(C_{\text {rain }}=0.17 C_{a i r}+125 \mid r=0.56\right)$ than for CP events with $R$ $298<10 \mathrm{~mm} \mathrm{~h}^{-1}\left(\mathrm{C}_{\text {rain }}=0.66 \mathrm{C}_{\text {air }}+448 \mid \mathrm{r}=0.36\right)$.

299 This allows us to calculate WR for each event using equation (1), and to document the dependency 300 of the WR with the precipitation amount.

301
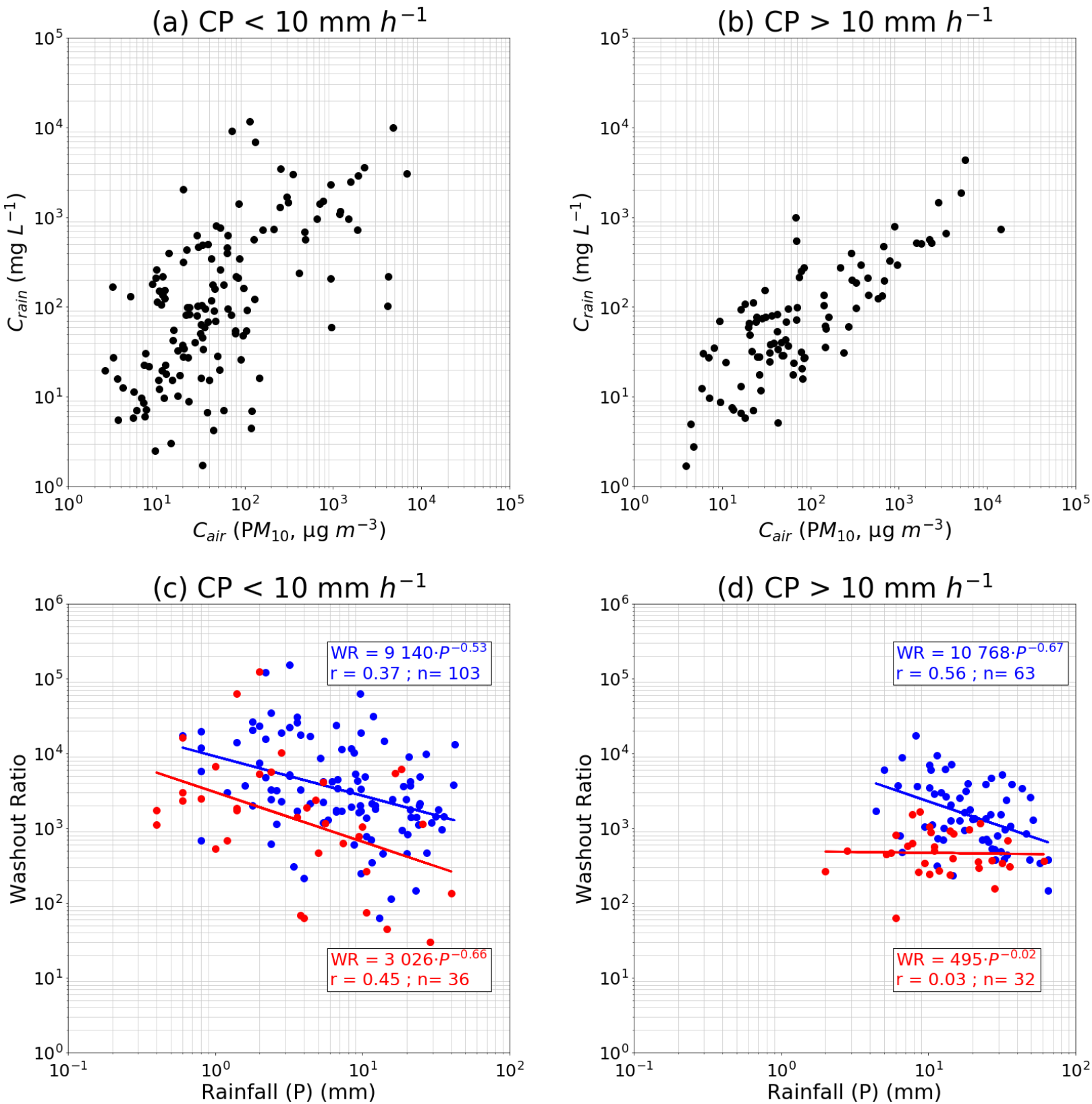

302

303

304

305

306

307

308

Figure 2. (a-b) Concentration of particles in rain $\left(\mathrm{C}_{\text {rain }}, \mathrm{mg} \mathrm{L}^{-1}\right)$ as a function of surface $\mathrm{PM}_{10}$ concentration $\left(\mathrm{C}_{\text {air }}, \mu \mathrm{g} \mathrm{m}^{-3}\right)$ for $\mathrm{CP}$ events in both sites for, (a) CP with $\mathrm{R}<10 \mathrm{~mm} \mathrm{~h}^{-1}(\mathrm{n}=139)$ and (b) $C P$ with $R \geq 10 \mathrm{~mm} \mathrm{~h}^{-1}(\mathrm{n}=95)$. (c-d) Washout ratios as a function of rainfall $(\mathrm{P}, \mathrm{mm})$ in both sites for, (c) $\mathrm{CP}$ with $\mathrm{R}<10 \mathrm{~mm} \mathrm{~h}^{-1}$ and (d) $\mathrm{CP}$ with $\mathrm{R} \geq 10 \mathrm{~mm} \mathrm{~h}^{-1}$ and regarding two concentrations regimes : in blue, $\mathrm{C}_{\text {air }}<100 \mu \mathrm{g} \mathrm{m}^{-3}$ and in red, $\mathrm{C}_{\text {air }} \geq 100 \mu \mathrm{g} \mathrm{m}^{-3}$. 
Figures 2 (c-d) illustrate the variation of the WR as a function of the rainfall. The results are presented for two dust concentration regimes higher and lower than $100 \mu \mathrm{g} \mathrm{m}^{-3}$. One can observe a decreasing trend of the WR with the rainfall amount for $\mathrm{CP}$ events associated to $\mathrm{R}<10 \mathrm{~mm} \mathrm{~h}^{-1}$ for both concentrations regimes (figure 2-c). This is due to the so-called dilution effect (Desboeufs et al., 2010; Jaffrezo et al., 1990; Marticorena et al., 2017): the first drops have a higher washout efficiency due to the fact that $\mathrm{PM}_{10}$ concentration is higher at the beginning of the rain. The longer it rains, the fewer dust particles are left in the atmosphere for being scavenged; therefore, at the later stage of a rain event, the below-cloud air is devoid of aerosols and scavenging occurs mostly by rainout. Although the decreasing trends in washout ratios resemble each other for concentrations above or below the $100 \mu \mathrm{g} \mathrm{m}^{-3}$ threshold, the WR is always significantly higher for $\mathrm{CP}$ events with concentrations below that threshold. Regarding CP events with $\mathrm{R} \geq 10 \mathrm{~mm} \mathrm{~h}^{-1}$, it can be seen that for the same rainfall amount, the WR is greater for $\mathrm{CP}$ events under low concentrations regime and, unlike the latter, there is no dilution effect for $\mathrm{CP}$ events under high concentrations regime (figure 2-d).

To estimate dust deposition over oceanic surfaces, Duce et al. (1991) used for dust particles a WR= 200 for the North Atlantic Ocean, based on measurements done at Bermuda and Miami (Church et al., 1984; Prospero et al., 1987) and 1000 for other oceans using data obtained in the Pacific Ocean region from Japanese network (e.g., Tsunogai and Kondo, 1982), and from Sea-Air Exchange (SEAREX) Program and related project (e.g., Arimoto et al., 1987; Uematsu et al., 1985).

According to an event-based study of nearly 240 wet deposition events collected over almost a decade in two Sahelian sites, our results suggest that the assumption of a single WR value is not valid in a Sahelian environment. Indeed, it is necessary to take into account the dilution effect for some categories of events, i.e., CP events associated with low concentrations regime $\left(<100 \mu \mathrm{g} \mathrm{m} \mathrm{m}^{-}\right.$ $\left.{ }^{3}\right)$ as well as $\mathrm{CP}$ events associated with high concentrations and low rainfall rates $\left(\mathrm{R}<10 \mathrm{~mm} \mathrm{~h}^{-}\right.$ ${ }^{1}$ ). However, for the most convective events (i.e., $C P$ with $\mathrm{R} \geq 10 \mathrm{~mm} \mathrm{~h}^{-1}$ ) under a high dust concentrations regime, the use of a WR between 319 and 766 seems reasonable considering the absent dilution effect and the lower dispersion of values. This range of value is in the lower range of values reported by Duce et al. (1991) and slightly higher than the washout ratios reported in the

\section{Conclusions}

348 Wet deposition fluxes, meteorological parameters and $\mathrm{PM}_{10}$ concentrations have been analysed at 349 the event scale using a 9-year data set (2007-2015). Annual wet deposition ranged from 38.0 to $350117.6 \mathrm{~g} \mathrm{~m}^{-2} \mathrm{yr}^{-1}$ and from 43.2 to $116.2 \mathrm{~g} \mathrm{~m}^{-2} \mathrm{yr}^{-1}$ in Banizoumbou and Cinzana, respectively, for complete years with continuous measurements. 
353 We used meteorological criteria to distinguish rain events associated with Cold Pools (CP). 273

354 and 399 rain events were associated with $\mathrm{CP}$ characterized by $\Delta \mathrm{T} \geq 2.0^{\circ} \mathrm{C}, \Delta \mathrm{V}<0 \mathrm{~m} \mathrm{~s}^{-1}$ and $\Delta \mathrm{Dir}$

$355 \geq 30^{\circ}$, while 89 and 121 rain events were not associated with cold pools (NCP) in Banizoumbou

356 and Cinzana, respectively. We found that CP and NCP events contribute to 66 to $81 \%$ and 1 to $7 \%$

357 respectively of total studied wet deposition while they account for between 91 to $93 \%$ and 7 to $9 \%$

358 respectively of total studied precipitation amount.

360 Relationships between concentrations of particles in rain and surface $\mathrm{PM}_{10}$ concentrations have

361 been studied for CP events associated to rainfall higher and lower than $10 \mathrm{~mm} \mathrm{~h}^{-1}$. Significant

362 correlations have been found and allowed us to calculate washout ratios (WR). Since the

363 assumptions of representativeness of surface concentrations and homogeneity of the column under

364 the cloud are not fulfilled for NCP events, we focus here on the determination of WR for CP events.

365 Our results suggest that, for the same amount of precipitation, the WR is higher for CPs under a

366 low concentration regime, regardless of the rain intensity.

\section{Acknowledgments}

374 Measurements in Banizoumbou and Cinzana are performed in the framework of the French 375 National Observatory Services INDAAF that is supported since 2010 by the Observatoire des 376 Sciences de l'Univers EFLUVE, the INSU/CNRS and the IRD. This work has also strongly 377 benefited from the support of the colleagues in Niger and Mali, thanks to all of them. The treatment of the data was performed in the framework of the research programs DATSHA supported by the French national program LEFE (Les Enveloppes Fluides et Environnement) and Fondation Air Liquide and DustClim supported by the European Commission under the ERA4CS action - Joint Call on Researching and Advancing Climate Services Development, Grant Agreement no. 690462 - ERA4CS - H2020-SC5-2014-2015/H2020-SC5-2015-one-stage.

The data are distributed through the INDAAF website: https://indaaf.obs-mip.fr/ and avalaible at the web link http://www.lisa.u-pec.fr/fr/donnees by Laboratoire Interuniversitaire des Systèmes Atmosphériques. 


\section{References}

Abdourhamane Toure, A., Rajot, J. L., Garba, Z., Marticorena, B., Petit, C., \& Sebag, D. (2011). Impact of very low crop residues cover on wind erosion in the Sahel. CATENA, 85(3), 205214. https://doi.org/10.1016/j.catena.2011.01.002

A.M.S. (2015). Mesoscale convective system - Glossary of meteorology. Retrieved June 26, 2020, from http://glossary.ametsoc.org/wiki/Mesoscale_convective_systems

Arimoto, R., Duce, R. A., Ray, B. J., Hewitt, A. D., \& Williams, J. (1987). Trace elements in the atmosphere of American Samoa: Concentrations and deposition to the tropical South Pacific. Journal of Geophysical Research: Atmospheres, 92(D7), 8465-8479. https://doi.org/10.1029/JD092iD07p08465

Bagnold, R. A. (1941). The physics of blown sand and desert dunes. William Morrow \& Company. Balkanski, Y., Bonnet, R., Boucher, O., Checa-Garcia, R., \& Servonnat, J. (2021). Better representation of dust can improve climate models with too weak an African monsoon. Atmospheric Chemistry and Physics, 21(14), 11423-11435. https://doi.org/10.5194/acp21-11423-2021

Bergametti, G., Marticorena, B., Rajot, J. L., Chatenet, B., Féron, A., Gaimoz, C., et al. (2017). Dust Uplift Potential in the Central Sahel: An Analysis Based on 10 years of Meteorological Measurements at High Temporal Resolution. Journal of Geophysical Research: Atmospheres, 122(22), 12,433-12,448. https://doi.org/10.1002/2017JD027471

Boucher, O., Randall, D., Artaxo, P., Bretherton, C., Feingold, G., \& Forster, P. (2013). Clouds and Aerosols. In Climate Change 2013 - The Physical Science Basis: Working Group I Contribution to the Fifth Assessment Report of the Intergovernmental Panel on Climate Change (Cambridge University Press, pp. 571-658). Cambridge. https://doi.org/10.1017/CBO9781107415324.016

Cerqueira, M., Pio, C., Legrand, M., Puxbaum, H., Kasper-Giebl, A., Afonso, J., et al. (2010). Particulate carbon in precipitation at European background sites. Journal of Aerosol Science, 41(1), 51-61. https://doi.org/10.1016/j.jaerosci.2009.08.002

Chamberlain, A. C. (1960). Aspects of the deposition of radioactive and other gases and particles. Intern. J. Air Pollution, Vol: 3.

Cheng, I., Al Mamun, A., \& Zhang, L. (2021). A synthesis review on atmospheric wet deposition of particulate elements: scavenging ratios, solubility, and flux measurements. Environmental Reviews, 29(3), 340-353. https://doi.org/10.1139/er-2020-0118

Church, T. M., Tramontano, J. M., Scudlark, J. R., Jickells, T. D., Tokos, J. J., Knap, A. H., \& Galloway, J. N. (1984). The wet deposition of trace metals to the western atlantic ocean at the mid-atlantic coast and on Bermuda. Atmospheric Environment (1967), 18(12), 26572664. https://doi.org/10.1016/0004-6981(84)90330-5

Desboeufs, K., Journet, E., Rajot, J.-L., Chevaillier, S., Triquet, S., Formenti, P., \& Zakou, A. (2010). Chemistry of rain events in West Africa: evidence of dust and biogenic influence in convective systems. Atmospheric Chemistry and Physics, 10(19), 9283-9293. https://doi.org/10.5194/acp-10-9283-2010

Di Biagio, C., Balkanski, Y., Albani, S., Boucher, O., \& Formenti, P. (2020). Direct Radiative Effect by Mineral Dust Aerosols Constrained by New Microphysical and Spectral Optical Data. Geophysical Research Letters, 47(2), e2019GL086186. https://doi.org/10.1029/2019GL086186

Drees, L. R., Manu, A., \& Wilding, L. P. (1993). Characteristics of aeolian dusts in Niger, West Africa. Geoderma, 59(1), 213-233. https://doi.org/10.1016/0016-7061(93)90070-2 
Duce, R. A., Liss, P. S., Merrill, J. T., Atlas, E. L., Buat-Menard, P., Hicks, B. B., et al. (1991). The atmospheric input of trace species to the world ocean. Global Biogeochemical Cycles, 5(3), 193-259. https://doi.org/10.1029/91GB01778

Ducret, J., \& Cachier, H. (1992). Particulate carbon content in rain at various temperate and tropical locations. Journal of Atmospheric Chemistry, 15(1), 55-67. https://doi.org/10.1007/BF00053609

Encinas, D., Calzada, I., \& Casado, H. (2004). Scavenging Ratios in an Urban Area in the Spanish Basque Country. Aerosol Science and Technology, 38(7), 685-691. https://doi.org/10.1080/02786820490460716

Flamant, C., Knippertz, P., Parker, D. J., Chaboureau, J.-P., Lavaysse, C., Agusti-Panareda, A., \& Kergoat, L. (2009). The impact of a mesoscale convective system cold pool on the northward propagation of the intertropical discontinuity over West Africa. Quarterly Journal of the Royal Meteorological Society, 135(638), 139-159. https://doi.org/10.1002/qj.357

Gatz, D. F. (1974). Scavenging ratio measurements in METROMEX. In Proc. of Symp. on Precipitation Scavenging (pp. 71-87). Champaign, Illinois, USA: CONF 741003 NTIS Springfield.

Ginoux, Paul, Chin, M., Tegen, I., Prospero, J. M., Holben, B., Dubovik, O., \& Lin, S.-J. (2001). Sources and distributions of dust aerosols simulated with the GOCART model. Journal of Geophysical Research: Atmospheres, 106(D17), 20255-20273. https://doi.org/10.1029/2000JD000053

Guerzoni, S., Cristini, A., Caboi, R., Le Bolloch, O., Marras, I., \& Rundeddu, L. (1995). Ionic composition of rainwater and atmospheric aerosols in Sardinia, southern Mediterranean. Water, Air, and Soil Pollution, 85(4), 2077-2082. https://doi.org/10.1007/BF01186140

Harrison, T. C., Washington, R., \& Engelstaedter, S. (2021). Satellite-Derived Characteristics of Saharan Cold Pool Outflows During Boreal Summer. Journal of Geophysical Research: Atmospheres, 126(3), e2020JD033387. https://doi.org/10.1029/2020JD033387

Herrmann, L. (1996). Staubdeposition auf Böden West-Afrikas: Eigenschaften und Herkunftsgebiete der Stäube und ihr Einfluss auf Boden und Standortseigenschaften $(\mathrm{PhD}$ dissertation). Univ. Hohenheim, Stuttgart, Germany.

Houze, R. A. (1997). Stratiform Precipitation in Regions of Convection: A Meteorological Paradox? Bulletin of the American Meteorological Society, 78(10), 18. https://doi.org/10.1175/1520-0477(1997)078<2179:SPIROC>2.0.CO;2

Huneeus, N., Schulz, M., Balkanski, Y., Griesfeller, J., Prospero, M. J., Kinne, S., et al. (2011). Global dust model intercomparison in AeroCom phase I. Atmospheric Chemistry and Physics, 11, 7781-7816. https://doi.org/10.5194/acp-11-7781-2011

Jaffrezo, J.-L., Colin, J.-L., \& Gros, J.-M. (1990). Some physical factors influencing scavenging ratios. Atmospheric Environment. Part A. General Topics, 24(12), 3073-3083. https://doi.org/10.1016/0960-1686(90)90486-7

Jung, E., \& Shao, Y. (2006). An intercomparison of four wet deposition schemes used in dust transport modeling. Global and Planetary Change, 52(1), 248-260. https://doi.org/10.1016/j.gloplacha.2006.02.008

Kaly, F., Marticorena, B., Chatenet, B., Rajot, J. L., Janicot, S., Niang, A., et al. (2015). Variability of mineral dust concentrations over West Africa monitored by the Sahelian Dust Transect. Atmospheric Research, 164-165, 226-241. https://doi.org/10.1016/j.atmosres.2015.05.011 
Knippertz, P., Trentmann, J., \& Seifert, A. (2009). High-resolution simulations of convective cold pools over the northwestern Sahara. Journal of Geophysical Research: Atmospheres, 114(D8). https://doi.org/10.1029/2008JD011271

Laurent, H., D'Amato, N., \& Lebel, T. (1998). How important is the contribution of the mesoscale convective complexes to the Sahelian rainfall? Physics and Chemistry of the Earth, 23(5), 629-633. https://doi.org/10.1016/S0079-1946(98)00099-8

Leary, C. A., \& Houze, R. A. (1979). Melting and Evaporation of Hydrometeors in Precipitation from the Anvil Clouds of Deep Tropical Convection. Journal of the Atmospheric Sciences, 36(4), 669-679. https://doi.org/10.1175/1520-0469(1979)036<0669:MAEOHI>2.0.CO;2

Lebel, T., Diedhiou, A., \& Laurent, H. (2003). Seasonal cycle and interannual variability of the Sahelian rainfall at hydrological scales. Journal of Geophysical Research: Atmospheres, 108(D8). https://doi.org/10.1029/2001JD001580

Lu, H., \& Shao, Y. (2001). Toward quantitative prediction of dust storms: an integrated wind erosion modelling system and its applications. Environmental Modelling \& Software, 16(3), 233-249. https://doi.org/10.1016/S1364-8152(00)00083-9

Marsham, J. H., Parker, D. J., Grams, C. M., Taylor, C. M., \& Haywood, J. M. (2008). Uplift of Saharan dust south of the intertropical discontinuity. Journal of Geophysical Research: Atmospheres, 113(D21). https://doi.org/10.1029/2008JD009844

Marticorena, B., \& Bergametti, G. (1995). Modeling the atmospheric dust cycle: 1. Design of a soil-derived dust emission scheme. Journal of Geophysical Research, 100(D8), 16415. https://doi.org/10.1029/95JD00690

Marticorena, B., Chatenet, B., Rajot, J. L., Traore, S., Coulibaly, M., Diallo, A., et al. (2010). Temporal variability of mineral dust concentrations over West Africa: analyses of a pluriannual monitoring from the AMMA Sahelian Dust Transect. Atmospheric Chemistry and Physics, 10(18), 8899-8915. https://doi.org/10.5194/acp-10-8899-2010

Marticorena, B., Chatenet, B., Rajot, J. L., Bergametti, G., Deroubaix, A., Vincent, J., et al. (2017). Mineral dust over west and central Sahel: Seasonal patterns of dry and wet deposition fluxes from a pluriannual sampling (2006-2012). Journal of Geophysical Research: Atmospheres, 122(2), 1338-1364. https://doi.org/10.1002/2016JD025995

Mathon, V., Laurent, H., \& Lebel, T. (2002). Mesoscale Convective System Rainfall in the Sahel. Journal of Applied Meteorology, 41, 12. https://doi.org/10.1175/15200450(2002)041<1081:MCSRIT>2.0.CO;2

Nesbitt, S. W., \& Zipser, E. J. (2003). The Diurnal Cycle of Rainfall and Convective Intensity according to Three Years of TRMM Measurements. Journal of Climate, 16(10), 14561475. https://doi.org/10.1175/1520-0442(2003)016<1456:TDCORA>2.0.CO;2

Nicholson, S. E. (2013). The West African Sahel: A Review of Recent Studies on the Rainfall Regime and Its Interannual Variability. ISRN Meteorology, 2013, 1-32. https://doi.org/10.1155/2013/453521

Nzeukou, A., Sauvageot, H., Ochou, A. D., \& Kebe, C. M. F. (2004). Raindrop Size Distribution and Radar Parameters at Cape Verde. Journal of Applied Meteorology, 43(1), 90-105. https://doi.org/10.1175/1520-0450(2004)043<0090:RSDARP>2.0.CO;2

Orange, D. (1990). Mesure du dépôt au sol des aérosols désertiques. Une méthode simple de prélèvement: le capteur pyramidal. Comptes Rendus de l'Académie des Sciences.Série 2 : Mécanique..., 311(1), 167-172.

Prospero, J. M., Nees, R. T., \& Uematsu, M. (1987). Deposition rate of particulate and dissolved aluminum derived from saharan dust in precipitation at Miami, Florida. Journal of 


\section{Geophysical Research: Atmospheres,} https://doi.org/10.1029/JD092iD12p14723

Provod, M., Marsham, J. H., Parker, D. J., \& Birch, C. E. (2016). A Characterization of Cold Pools in the West African Sahel. Monthly Weather Review, 144(5), 1923-1934. https://doi.org/10.1175/MWR-D-15-0023.1

Pye, K. (1987). Aeolian dust and dust deposits (p. 334). Elsevier.

Rajot, J. L., Formenti, P., Alfaro, S., Desboeufs, K., Chevaillier, S., Chatenet, B., et al. (2008). AMMA dust experiment: An overview of measurements performed during the dry season special observation period (SOP0) at the Banizoumbou (Niger) supersite. Journal of Geophysical Research, 113, D00C14. https://doi.org/10.1029/2008JD009906

Ramsperger, B., Herrmann, L., \& Stahr, K. (1998). Dust characteristics and source-sink relations in eastern West Africa (SW-Niger and Benin) and South America (Argentinean Pampas). Zeitschrift Für Pflanzenernährung Und Bodenkunde, 161(4), 357-363. https://doi.org/10.1002/jpln.1998.3581610404

Rott, C. (2001). Saharan sand and dust-characterisation, deposition rates and implications (Master Thesis). Royal Holloway University of London, Egham, UK.

Schumacher, C., \& Houze, R. A. (2006). Stratiform precipitation production over sub-Saharan Africa and the tropical East Atlantic as observed by TRMM. Quarterly Journal of the Royal Meteorological Society, 132(620), 2235-2255. https://doi.org/10.1256/qj.05.121

Shao, Y., \& Lu, H. (2000). A simple expression for wind erosion threshold friction velocity. Journal of Geophysical Research: Atmospheres, 105(D17), 22437-22443. https://doi.org/10.1029/2000JD900304

Slinn, W. G. N. (1974). Precipitation scavenging: some problems, approximate solutions, and suggestions for future research in Precipitation Scavenging. In Proc. of Symp. on Precipitation Scavenging (pp. 1-60). Champaign, Illinois, USA: CONF 741003 NTIS Springfield.

Sow, M., Alfaro, S. C., Rajot, J. L., \& Marticorena, B. (2009). Size resolved dust emission fluxes measured in Niger during 3 dust storms of the AMMA experiment. Atmos. Chem. Phys., 11.

Tegen, I., \& Fung, I. (1994). Modeling of mineral dust in the atmosphere: Sources, transport, and optical thickness. Journal of Geophysical Research: Atmospheres, 99(D11), 22897-22914. https://doi.org/10.1029/94JD01928

Tegen, I., \& Lacis, A. A. (1996). Modeling of particle size distribution and its influence on the radiative properties of mineral dust aerosol. Journal of Geophysical Research: Atmospheres, 101(D14), 19237-19244. https://doi.org/10.1029/95JD03610

Textor, C., Schulz, M., Guibert, S., Kinne, S., Balkanski, Y., Bauer, S., et al. (2006). Analysis and quantification of the diversities of aerosol life cycles within AeroCom. Atmos. Chem. Phys., 37. https://doi.org/10.5194/acp-6-1777-2006

Tsunogai, S., \& Kondo, T. (1982). Sporadic transport and deposition of continental aerosols to the Pacific Ocean. Journal of Geophysical Research: Oceans, 87(C11), 8870-8874. https://doi.org/10.1029/JC087iC11p08870

Uematsu, M., Duce, R. A., \& Prospero, J. M. (1985). Deposition of atmospheric mineral particles in the North Pacific Ocean. Journal of Atmospheric Chemistry, 3(1), 123-138.

Vischel, T., Panthou, G., Peyrillé, P., Roehrig, R., Quantin, G., Lebel, T., et al. (2019). Chapter 4 - Precipitation Extremes in the West African Sahel: Recent Evolution and Physical 
Mechanisms. In V. Venugopal, J. Sukhatme, R. Murtugudde, \& R. Roca (Eds.), Tropical Extremes (pp. 95-138). Elsevier. https://doi.org/10.1016/B978-0-12-809248-4.00004-2 (2009). The electrification of dust-lofting gust fronts ('haboobs') in the Sahel. Atmospheric Research, 91(2), 292-298. https://doi.org/10.1016/j.atmosres.2008.05.017

Wilson, J. W., \& Schreiber, W. E. (1986). Initiation of Convective Storms at Radar-Observed Boundary-Layer Convergence Lines. Monthly Weather Review, 114(12), 2516-2536. https://doi.org/10.1175/1520-0493(1986)114<2516:IOCSAR>2.0.CO;2 